\title{
Situating the accountability of the UN Security Council: Between liberal-legal and political 'styles' of global constitutionalism?
}

\author{
B E N L. M U R P H Y \\ School of Law and Social Justice, University of Liverpool, United Kingdom
}

Email: b.l.murphy@liverpool.ac.uk

\begin{abstract}
Accountability' is the international legal term $d u$ jour. The concept is omnipresent in contemporary discussions about the UN Security Council in particular. From the lack of due process guarantees for individuals implicated in its counter-terrorism sanctions regime, to the (in)compatibility of Council authorized uses of force with international human rights and humanitarian law, no aspect of the Council's recent practice has been immune from an accountability critique. Driven by the context in which it has emerged, the turn to accountability is seemingly prompted by a felt desire among international lawyers to constrain the arbitrary use of the Council's considerable powers. However, beyond this felt desire, the concept lacks a robust theoretical foregrounding, both on its own terms and in relation to existential developments in international law. In an attempt to remedy this, this article situates the turn to accountability as a product of the broader turn to 'constitutionalist' thinking in international law. Specifically, it suggests that mainstream approaches resonate with a particular 'liberal-legalist style' of global constitutionalism. From both an etymological and epistemological perspective, however, I argue that this prevailing style offers an incomplete sense of accountability. The article introduces the dichotomy of 'liberal-legal' and more overtly 'political' styles of global constitutionalism as a heuristic device in order to offer a broader conception of accountability in the Security Council context. Political constitutionalism, I believe, offers important insights that will allow us to perceive and critique the Security Council in new ways.
\end{abstract}

Keywords: accountability; global constitutionalism; liberal-legalism; political constitutionalism; UN Security Council

\section{Introduction}

On 12 September 2018, the UN General Assembly met to consider the UN Security Council's annual report on measures taken under its primary responsibility for the maintenance of international peace and security. The Assembly does not typically engage closely with this report. In the same meeting in 2017, it was noted that the debate had become a 'ritual',

${ }^{1}$ UNGA Official Records, $71^{\text {st }}$ session, $95^{\text {th }}$ meeting (28 August 2017) UN Doc A/71/ PV.95 at 5 . 
representing 'one more formality in a long list of formalities'. ${ }^{2}$ While only two states took to the floor, this time the thrust of their respective interventions was substantively different. Gholamali Khoshroo, the representative of Iran, took issue in strong terms with Security Council interventions into a state's 'internal affairs, interference in which is explicitly prohibited by the Charter'. ${ }^{3}$ Wei'en John Khoo, representing Singapore, adopted a similarly critical posture. He suggested that 'the sovereign rights of States, as well as human rights, have been seriously violated'. ${ }^{4}$ He concluded, 'if unchecked, this alarming trend will further tarnish the credibility of the Organization and this Council, eroding the rule of law and leading to international disorder' ${ }^{5}$ Crucially, the speakers couched their critique using exactly the same frame of reference, separately noting that the Security Council must be more 'accountable'. ${ }^{6}$

For member states to explicitly suggest that the primary political organ of the United Nations should be accountable for its actions represents a monumental shift in the manner in which this term is typically used. For ten years between 2003 and 2013, the question of 'the promotion and strengthening of the rule of law in the maintenance of international peace and security' was a standing item on the Council's agenda. In its final statement on the matter, the Council stressed that the importance of the 'fight against impunity ... to ensure accountability for genocide, crimes against humanity, war crimes and other egregious crimes'. ${ }^{7}$ This shows that, if anything, the Council sees itself primarily as a promoter of the accountability of others, whether states, non-state groups or individuals. As evidenced by this more recent debate, it seems that now the shoe is on the other foot. The accountability of the Council itself is under the spotlight.

This shift resonates with a broader move in international legal discourse. It is difficult to think of a single issue of contemporary significance to international lawyers that a recent 'turn to accountability' has overlooked, but this is especially true when it comes to international organizations. ${ }^{8}$ The

${ }^{2}$ UNGA Official Records, $72^{\text {nd }}$ session, $114^{\text {th }}$ meeting (12 September 2018) UN Doc A/72/ PV.114 at 2.

${ }^{3}$ Ibid at 3.

${ }^{4}$ Ibid.

${ }^{5}$ Ibid at 4.

${ }^{6}$ The Iranian representative suggested that the Council 'should remain accountable to the General Assembly, which encompasses all States Members of the United Nations and on whose behalf the Council acts', and the representative of Singapore gave several suggestions to 'promote greater accountability for the Security Council, not only to the wider membership but also to the international community': ibid at 3 (in both cases, emphasis added).

${ }^{7}$ UN Doc S/PRST/2014/5 (21 February 2014) at 3.

8 The literature is extremely voluminous. See, for an indicative sample, C Ferstman, International Organizations and the Fight for Accountability (OUP 2017); J Klabbers, 'Unity, 
Security Council is, of course, not an international organization per se, but an organ of the UN as its parent organization. In recent years, however, the Council's practice has courted a high degree of controversy, giving rise to a body of scholarly discourse on the accountability of the Security Council specifically. ${ }^{9}$ Notable examples of this practice include, inter alia, accusations of sexual assault and exploitation by Council-mandated peacekeepers, ${ }^{10}$ clear evidence of their responsibility for the cholera epidemic in Haiti, ${ }^{11}$ the blacklisting of individuals on terrorist sanctions lists without due process guarantees ${ }^{12}$ and controversial authorizations of the use of military force. ${ }^{13}$

The accountability discourse has thus emerged in a very specific context: as a response to these apparent excesses in the exercise of the Security Council's considerable power under Chapter VII of the UN Charter. As

Diversity, Accountability: The Ambivalent Concept of International Organisation' (2013) $14 \mathrm{Mel}$ bourne Journal of International Law 149; J Klabbers, 'Controlling International Organizations: A Virtue Ethics Approach’ (2011) 8 International Organizations Law Review 285; J Wouters, E Brems, S Smis and P Schmitt (eds), Accountability for Human Rights Violations by International Organisations (Intersentia, Cambridge, 2010); G Hafner, 'Accountability of International Organizations - A Critical View' in Towards World Constitutionalism: Issues in The Legal Ordering of The World Community, edited by R St John Macdonald and DM Johnston (Martinus Nijhoff, The Hague, 2005) 585; A Reinisch, 'Securing the Accountability of International Organizations' (2001) 7 Global Governance 131. The topic has also been taken up by the International Law Association in its Report on the Accountability of International Organisations (Berlin Conference, 2004). The central themes also feature prominently in the International Law Commission's consideration of the linked idea of the 'responsibility' of international organizations: see 'Draft Articles on the Responsibility of International Organizations, with Commentaries', in the Report on the Work of its Sixty-third Session (26 April-3 June, and 4 July-12 August 2011), UN Doc $\mathrm{A} / 66 / 10$.

9 For example, P Webb and C Michaelsen (eds), Special Issue: 'Strengthening the Accountability of the UN Security Council' (2014) 19(3) Journal of Conflict and Security Law 385 and articles therein; V Gowlland-Debbas, 'The Security Council and Issues of Responsibility' (2011) 105 Proceedings of the Annual Meeting (American Society of International Law) 348; A Tzanakopoulos, Disobeying the Security Council: Countermeasures Against Wrongful Sanctions (Oxford University Press, Oxford, 2011) 2-6; V Lowe, A Roberts, J Welsh and D Zaum, 'Introduction' in The United Nations Security Council and War: The Evolution of Thought and Practice Since 1945, edited by V Lowe, A Roberts, J Welsh and D Zaum (Oxford University Press, Oxford, 2008) 1, 39-43.

10 R Freedman, 'UNaccountable: A New Approach to Peacekeepers and Sexual Abuse' (2018) 29(3) European Journal of International Law 961.

11 I Kurzban, B Lindstrom and S Jonsson, 'UN Accountability for Haiti's Cholera Epidemic' (2014) 108 AJIL Unbound 17.

12 D Hovell, The Power of Process: The Value of Due Process in Security Council Sanctions Decision-Making (Oxford University Press, Oxford, 2016); Tzanakopoulos (n 9); E de Wet, The Chapter VII Powers of the United Nations Security Council (Hart, Oxford, 2004).

13 Particularly the imprimatur granted to NATO's intervention in Libya, see UNSC Res 1973 (17 March 2011); C Henderson, 'Authority without Accountability? The UN Security Council's Authorization Method and Institutional Mechanisms of Accountability' (2014) 19(3) Journal of Conflict and Security Law 489. 
such, in the literature there is a tendency to define accountability in a rather reductive manner. In the Kelsenian, positivist tradition, which remains the 'lingua franca of international lawyers' ${ }^{14}$ accountability tends to stand as a synonym for the notion of control, specifically legal control. It is associated with attempts to constrain the Council by identifying binding legal obligations provided by the Charter as the Council's lex specialis or by general international law (as lex generalis) and ensuring that these obligations are enforced. ${ }^{15}$

This article is prompted by a doctrinal and conceptual scepticism about the current trajectory of the debate. On a doctrinal level, such accounts tend to dramatically overplay the level of agreement regarding what rules actually bind the Council and, if they are binding, how they came to be. On a conceptual level, by placing disproportionate attention on the notion of 'holding to account', it is difficult to identify a line of demarcation between accountability and the doctrine of international legal responsibility. For the international lawyer, this makes some sense. International responsibility has a particular grip on international legal imaginations. Yet one question lingers: what space does this leave for accountability as a stand-alone concept?

To recover space for accountability on its own terms - especially a version of accountability that is applicable to the Security Council - it is necessary to think about how and why this reductive understanding has developed. This article suggests that one way to read the turn to accountability is as a product of the emergence of an explicitly constitutionalist vernacular in international law. The general association between the concepts of 'accountability' and 'constitutionalism' is often taken for granted. On a base level, 'accountability talk' is a perennial feature of everyday constitutional law and politics. ${ }^{16}$ However, this article argues that the relationship between the turn to

\footnotetext{
14 A Boyle and C Chinkin, The Making of International Law (Oxford University Press, Oxford, 2007) 12.

${ }^{15}$ It is in this relationship between obligation and enforcement that I describe the nascent accountability discourse as essentially Kelsenian. According to Kelsen's general theory, of course, 'the function determined by the legal order is the content of a legal obligation only if the legal order provides a sanction for the non-performance of the function': H Kelsen, The Law of the United Nations: A Critical Analysis of Its Fundamental Problems (Fredrick A Praeger, Westport, CT, 1950) 154.

${ }^{16} \mathrm{~N}$ Bamforth and P Leyland (eds), Accountability in the Contemporary Constitution (Oxford University Press, Oxford, 2013) 1: 'Ideas of accountability play a prominent role in contemporary discussions of constitutional law and practice, and politicians, judges and other actors tend frequently to claim, whatever the substantive viewpoint or proposal which they advocate, that more or better accountability is their end-goal'. Harlow even suggests that accountability has 'joined the classical trilogy of sovereignty, rule of law and separation of powers as a directive principle of constitutional law': C Harlow, Accountability in the European Union (Oxford University Press, Oxford, 2002) 7.
} 
Security Council accountability and the turn to (global) constitutionalist thinking in international law runs deeper than this. By pinpointing the chronological and normative links between these two sites of discourse, I want to suggest that it is impossible to understand one without reference to the other, to the point where the meaning of accountability in the Security Council context will necessarily be predicated on the perspective taken on global constitutionalism.

To show this, section II of this article surveys the turn to Security Council accountability and notes several blind-spots in the current debate. Section III situates the turn to accountability within the broader turn to the language of global constitutionalism in international law. Section IV introduces the distinction between 'liberal-legal' and 'political' styles of constitutionalism. This heuristic device is well established in Anglo-American constitutional thought ${ }^{17}$ and has been applied in the context of the European Union, ${ }^{18}$ but it is much less familiar to international lawyers. The central argument is that mainstream Kelsenian approaches are indicative of a prevailing liberallegalist style of global constitutionalism in international law; as such, many of the blind-spots in contemporary discussions on Security Council accountability are born directly in the constraints of liberal-legalism. In Section V, I suggest that a broader conception of accountability through the lens of a more overtly political (global) constitutionalism can elucidate new ways to perceive and, importantly, to critique the Security Council.

\section{The turn to Security Council accountability}

It is something of a truism to suggest that the Security Council wields great power under Chapter VII of the UN Charter. In the fulfilment of its 'primary responsibility for the maintenance of international peace and security', ${ }^{19}$ the Council can impose a range of enforcement measures, from non-forcible measures (namely economic sanctions) to coercive measures, including the

17 R Bellamy, Political Constitutionalism: A Republican Defence of the Constitutionality of Democracy (Cambridge University Press, Cambridge, 2007); A Tomkins, Our Republican Constitution (Hart, Oxford, 2005). Although perhaps more ambivalent about the distinction between liberal-legal and political constitutionalism, the scholarship of Waldron, Loughlin and Tushnet, respectively, might also be characterized as attempts to capture and transcend the tensions explored in this article. See especially J Waldron, Law and Disagreement (Oxford University Press, Oxford, 1999); M Loughlin, The Idea of Public Law (Oxford University Press, Oxford, 2004); M Tushnet, Taking the Constitution Away from the Courts (Princeton University Press, Princeton, NJ, 1999).

18 MA Wilkinson, 'Political Constitutionalism and the European Union' (2013) 76(2) Modern Law Review 191.

${ }^{19}$ UN Charter (1945), art 24(1). 
authorization of military force. ${ }^{20}$ Crucially, these measures are binding on all member states. ${ }^{21}$ The cumulative effect of these provisions is that the Council is surely the most powerful institution in global politics. According to the International Law Association, 'power entails accountability, that is the duty to account for its exercise'. ${ }^{22}$ The recent shift towards thinking about the Security Council in terms of its accountability is best understood in light of three chronological 'waves'.

During the first wave, there was almost no discussion of limiting the power of the Security Council, let alone broader questions of accountability. There are two main explanations for this. The doctrinal explanation is that international law had not yet come to terms with the legal relationship between international organizations and their member states. As a corollary of the legal personality of the United Nations, it is accepted that the organization and its organs enjoy both rights and responsibilities in international law. ${ }^{23}$ However, even at this early stage the absence of court or tribunal with compulsory jurisdiction to enforce these responsibilities whatever they were - was perceived as the most pressing challenge. ${ }^{24}$ For Kelsen, in the absence of judicial enforcement, the only possible conclusion was that 'the Security Council is not bound strictly to comply with existing law'. ${ }^{25}$ The more practical explanation is that because of the ideological differences that existed between permanent, veto-wielding members, during the Cold War the Council was stuck in a near-perpetual state of political paralysis. Its immense power remained largely hypothetical. Caught between a rock and a hard place, the latter was the Council's permanent residency due to its composition and voting privileges. ${ }^{26}$

The second wave began in the 1990s, as a revitalized Security Council displayed an increased willingness to exercise its powers - that is, to

${ }^{20}$ UN Charter (1945), arts 39, 41 and 42.

${ }^{21}$ UN Charter (1945), arts 25 and 103.

22 ILA Report (n 8) at 5.

23 Reparations Suffered in the Service of the United Nations (Advisory Opinion) [1949] ICJ Rep 174 at 179 . The Court has also recognized that ultra vires acts can be attributed to the United Nations in Certain Expenses of the United Nations (Advisory Opinion) [1962] ICJ 151 at paras 167-68.

${ }^{24}$ RY Jennings, 'Nullity and Effectiveness in International Law' in Cambridge Essays in International Law: Essays in Honour of Lord McNair (Stevens and Sons, London, 1965) 64, 86: 'the enervating effect of the lack, or near lack, of courts with compulsory jurisdiction is nowhere more damaging than in this aspect of international law'.

${ }^{25}$ Kelsen (n 15) 275. Seyersted proffered that any limits on the powers of the United Nations and its organs were 'internal, constitutional matters', which did not 'affect the external capacity of the organization under international law': F Seyersted, 'United Nations Forces - Some Legal Problems' (1961) 37 British Yearbook of International Law 351 at 460.

26 See UN Charter (1945), art 27(3). 
(figuratively) throw rocks. Whether using its Chapter VII powers, inter alia, to force Libya to surrender for trial the individuals accused of carrying out the bombing of Pan Am Flight 103 over Lockerbie, Scotland, ${ }^{27}$ to create international criminal tribunals, ${ }^{28}$ to 'legislate' counter-terrorism policies for all states, ${ }^{29}$ or to authorize the use of military force in conflicts that are not strictly 'international' in nature', ${ }^{30}$ the Council expanded its original mandate to the point where today its reach extends beyond anything that could have been anticipated by the drafters of the Charter. In what might be described as a fledging accountability discourse (although the term was not yet in widespread use), during this second wave legal commentators grappled with previously unforeseen questions: Is there a limit to the Council's discretion under Chapter VII of the UN Charter? Do member states have to comply with all decisions even if they appear ultra vires? Importantly, the Kelsenian anxiety relating to judicial review was not tangential to, but in fact formed the central theme of, this second wave. ${ }^{31}$

We are currently living in a third wave, which is defined by an important semantic shift: the scrutiny now has a frame of reference, the objective is to constrain - or even control - the Security Council, to find the means through which to ensure its legal accountability. Much of this discussion has taken place in the context of Article 41 sanctions, especially the 1267 sanctions regime, which subjects individuals and entities with suspected links to Al-Qaida and associated groups now including ISIL (Da'esh) to widespread

27 UNSC Res 748 (31 March 1992), preamble and paras 4-7.

28 UNSC Res 827 (25 May 1993) and UNSC Res 955 (8 November 1994) (establishing the International Criminal Tribunals for the Former Yugoslavia and Rwanda respectively).

${ }^{29}$ UNSC Res 1373 (28 September 2001).

30 See, at the extremity, UNSC 940 (31 July 1994), at para 4 (authorizing 'all necessary means' to enforce the result of a democratic election in Haiti). Under Article 39 of the Charter, a threat to international peace is commonly understood as a prerequisite to Chapter VII measures.

${ }^{31}$ It was given impetus by the International Court of Justice's flirtation with incidental review in Questions of Interpretation and Application of the 1971 Montreal Convention Arising from the Aerial Incident at Lockerbie (Libyan Arab Jamahiriya $v$ United Kingdom; Libyan Arab Jamahiriya $v$ United States of America) (Provisional Measures) [1992] ICJ Rep 3. This impetus was further spurred by the since oft-quoted passage from the International Criminal Tribunal for the Former Yugoslavia's Tadic decision: 'neither the text nor the spirit of the Charter conceives of the Security Council as legibus solutus (unbound by law)': Prosecutorv Tadić (Judgment, Appeals Chamber) [1999] ICTY-94-1 at para 28. In the literature, see D Akande, 'The International Court of Justice and the Security Council: Is there Room for Judicial Control of Decisions of the Political Organs of the United Nations?' (1997) 46(2) International and Comparative Law Quarterly 309; JE Alvarez, 'Judging the Security Council' (1996) 90 American Journal of International Law 1; V Gowlland-Debbas, 'The Relationship Between the International Court of Justice and the Security Council in the Light of the Lockerbie Case' (1994) 88 American Journal of International Law 643. For an alternative perspective, see GH Oosthuizen, 'Playing the Devil's Advocate: The United Nations Security Council is Unbound by Law' (1999) 12 Leiden Journal of International Law 521. 
measures including asset freezing and travel restrictions. ${ }^{32}$ The situation of an individual listed under the 1267 regime has been compared with that of Josef $\mathrm{K}$ in Kafka's The Trial, 'who awakens one morning and for reasons never revealed to him or the reader is arrested and prosecuted for an unspecified crime'. ${ }^{33}$ The sanctions example demonstrates well the two interconnected factors that are driving the third wave of accountability discourse. The first is the individualization of the consequences of Security Council decisions. ${ }^{34}$ The second is the felt need to judicially enforce obligations incumbent upon the Council - especially human rights obligations - to protect individual rights. ${ }^{35}$

With these two factors in mind, it is telling that accountability is often packaged with the doctrine of international responsibility. At its root, international responsibility consists of three interrelated premises. First, actors who enjoy international legal personality have a duty to uphold their legal obligations. Second, a failure to uphold these obligations triggers the 'responsibility' of that actor. Finally, as a corollary to that responsibility, the actor agrees to accept the legal consequences that flow therefrom. ${ }^{36} \mathrm{Cru}-$ cially, these premises not only constitute the doctrine of international responsibility but provide the foundational organizing principle of the international legal order itself. In this sense, the association of accountability and responsibility is logical - intuitive even. As Krisch perceptively notes, 'It is natural human behaviour to fill voids with what we know. When we are thrown into unfamiliar spaces, we try to chart them with the maps we possess, construct them with the tools we already have. ${ }^{37}$ The doctrine of international responsibility is indeed a map familiar to the international legal lexicon. There is perhaps no more familiar map.

Underpinning this intuition, however, is a more normative connotation. Where there is doubt as to whether accountability is an intrinsically legal

32 UNSC Res 1267 (15 October 1999); UNSC Res 1989 (17 June 2011); UNSC Res 2253 (17 December 2015); Tzanakopoulos (n 9) 2: 'recent interest in the accountability of international organizations is owed primarily to this extensive activity of the Security Council'.

${ }^{33}$ Hovell (n 12) 114.

34 See, for example, LJ van den Herik, 'The Individualization and Formalization of UN Sanctions' in Research Handbook on UN Sanctions and International Law, edited by LJ van den Herik, (Edward Elgar, Cheltenham, 2017) 1.

35 A Peters, 'Article 24' in B Simma et al, The Charter of the United Nations: A Commentary, Vol. 1 ( $3^{\text {rd }}$ ed, Oxford University Press, Oxford, 2012) 761, 810: 'the more powerful the Security Council gets, and the more its decisions interfere with (human) rights of individuals, the more necessary it is to build safeguards against the Council's potential abuse of powers, and against the possibility of a violation of those rights'.

${ }^{36}$ See, generally, International Law Commission, 'Draft Articles on the Responsibility of International Organizations' (n 8).

37 N Krisch, Beyond Constitutionalism: The Pluralist Structure of Postnational Law (Oxford University Press, Oxford, 2010) 27. 
concept ${ }^{38}$ there is no such doubt when it comes to the doctrine of international responsibility. It is, conversely, perceived as the 'toughest' branch of international law: 'it puts a harder edge on legal rights and duties'. ${ }^{39}$ Herein lies the appeal of international responsibility: it provides the leitmotif to achieve the ambition of holding the Security Council accountable in international law.

The above notwithstanding, the 'accountability as responsibility' thesis suffers from an inherent paradox. The very sentiment that drives the debate - the felt need to establish binding justiciable obligations - uses as its frame of reference a doctrine that relies, as its foundational basis, on the existence of these obligations. Where there is no obligation, therefore, there can be no responsibility. The paradox also has a further implication. Even where obligations do exist, they are typically only triggered by a positive affirmative decision of the Council. As we have seen, the accountability discourse has arisen predominantly in response to such decisions - for example, the establishment of criminal courts, the inclusion of individuals on sanctions lists, the authorization of the use of military force. It is the legality of a decision already made that determines whether the Council can be accountable for the consequences that flow from it.

Due to this limitation, the third wave of accountability discourse is unable to capture the breadth and depth of the Security Council's various accountability deficits. At this juncture, it is sufficient to note just three 'blind-spots'. The first is exemplified by the Council's response to the Paris terrorist attack of 2015. Resolution 2249 quickly determined that the perpetrators 'constitute an unprecedented threat to international peace and security'. ${ }^{40}$ However, while seemingly in agreement that a response of some sort was necessary, the permanent members of the Council were manifestly unable to reach a consensus on the substance of what that response should be. As a result, the resolution is inherently ambiguous. The operative paragraph 'Calls upon Member States ... to take all necessary measures ... on the territory under the control of ISIL ... in Syria and Iraq'. ${ }^{41}$ The problem with this ambiguity is that at the time the resolution was passed, a US-led coalition was already conducting airstrikes against ISIL bases in Syria, without the consent of the Syrian government. While not explicitly providing the legal basis for such strikes - for such resolutions normally explicitly 'decide' that states may, or 'authorize' states to use force - in 'calling upon'

38 D Curtin and A Nollkaemper, 'Conceptualizing Accountability in International and European Law' (2005) 36 Netherlands Yearbook of International Law 4 at 16.

39 Tzanakopoulos (n 9) 5-6.

40 UNSC Res 2249 (20 November 2015), preamble.

${ }^{41}$ Ibid, at para 5. 
members to take such measures, the resolution might easily be read as an implicit validation. ${ }^{42}$

In light of criticism from Syria and Russia of this apparent incursion of Syrian sovereignty, we might conceivably ask who is to be accountable. In the case of the Security Council, the question would have to be rephrased: How can we account for ambiguity? Indeed, beyond this example, ambiguity in Council resolutions is a perennial issue. ${ }^{43}$ However, from the perspective of international law, there is no 'duty to be clear', nor does the Charter impose any such obligation on the Security Council. ${ }^{44}$ This might explain why so little has been said about this aspect of the Security Council's practice in the accountability debate.

A second blind-spot relates to the controversial issue of Security Council inaction. While the expansive nature of the Council's practice is the focal point of the accountability discourse, the converse is not true: the concept has not been applied as systematically to situations in which the Council fails to act. It would be too much of a stretch to say that the Council's expansive practice has become the new status quo. Instead, the practice might more appropriately be categorized by its consistent inconsistency. For every example of enforcement action against perceived threats to international peace, a comparable situation meets inaction: for every Libya, there is a Syria, a Rwanda or a Srebrenica; for every rock a hard place. ${ }^{45}$ However, the scope of the Council's discretion under Chapter VII is almost completely unfettered. So, again, this aspect of the Council's practice is stymied by the 'accountability as responsibility' paradox. The positivist bent of accountability discourse means that its advocates struggle when it comes to nonlegal or at best 'quasi-legal' questions such as the material conditions that should trigger enforcement measures.

In a final blind-spot, legal commentators appear fixated on the notion of 'holding' the Security Council 'to account', a fixation that is aided and abetted by the conflation of accountability and legal responsibility. It is important to note, however, that the concept of accountability has three

42 D Akande and M Milanovic, The Constructive Ambiguity of the Security Council's ISIS Resolution' (21 November 2015) EJIL: Talk, available at <https://www.ejiltalk.org/the-construc tive-ambiguity-of-the-security-councils-isis-resolution>.

${ }^{43}$ See M Byers, 'Agreeing to Disagree: Security Council Resolution 1441 and Intentional Ambiguity' (2004) 10 Global Governance 165.

${ }^{44}$ Ibid 180: 'There is nothing in the Charter to suggest that the Security Council lacks the capacity to adopt a resolution that is deliberately open to different interpretations.'

45 When these failures are considered, they are addressed predominantly through the prism of 'responsibility'. See, for example, P Butchard, The Responsibility to Protect and the Failures of the United Nations Security Council (Hart, Oxford, 2020); J Klabbers, 'Reflections on Role Responsibility: The Responsibility of International Organizations for Failing to Act' (2017) 28(4) European Journal of International Law 1133. 
constitutive dimensions, not one. The first dimension is the expectation that an actor will explain and justify a decision ('give an account'), which is closely linked to the principle of transparency, accountability's 'alter-ego' ${ }^{46}$ In the absence of an explicit duty to give reasons in international law, this dimension is almost completely overlooked. The second dimension is the 'standard-setting' phase. Legal commentators naturally invoke the principle of legality as the relevant criteria for assessment, ignoring broader questions of the legitimization of Security Council decision-making. The final dimension is the 'consequences' phase. The third wave of accountability discourse is defined by a normative preference for judicial over political processes to impose these consequences. The adoption of such rigid positions masks significant internal contestation over the meaning and relative relevance of each dimension of accountability. The third wave has thus failed to engage with the concept of accountability in a holistic sense. ${ }^{47}$ Indeed, this conceptual lacuna is a key factor contributing to the more practical blind-spots relating to Security Council ambiguity and inaction.

\section{Accountability as a product of the turn to 'constitutionalism' in international legal thought}

The turn to Security Council accountability has not taken place in a vacuum. In this section, I suggest that the failure to grapple with accountability's internal conceptual contestation is rooted in the fact that international lawyers' eyes are fixed to certain existential tensions. ${ }^{48}$ These are categorized in the following paragraphs as a 'contractualism tension' (relating to the nature of international institutional authority), a 'functionalist tension' (relating to the prevailing legal theory to understand and rationalize this authority) and a 'fragmentation tension' (relating to the capacity of international law to respond to excesses of this authority). These tensions are linked thematically by the anxieties that they breed in the mind of the international lawyer. ${ }^{49}$

${ }^{46}$ Harlow (n 16) 7.

${ }^{47}$ In Section V, we return to this 'three-dimensional' approach to the concept of accountability, noting the range of accountability mechanisms available once a broader framework of analysis is adopted.

48 J D'Aspremont, Epistemic Forces in International Law: Foundational Doctrines and Techniques of International Legal Argumentation (Edward Elgar, Cheltenham, 2015) 139: 'paradigmatic tensions have ... always been constitutive of the field as well as the identity' of the discipline of international institutional law.

${ }^{49}$ On the notion of 'disciplinary anxieties', see, R Collins, The Institutional Problem in Modern International Law (Hart, Oxford, 2016) 225-34; M Koskenniemi and P Leino, 'Fragmentation of International Law? Postmodern Anxieties' (2002) 15 Leiden Journal of International Law 553. 
Although the idea of global constitutionalism is neither rooted in, nor did it emerge specifically from, public international law, its particular allure is apparent when set against these anxieties. Indeed, in an emerging methodological trend, constitutional imagery and analogies are invoked directly in juxtaposition to these tensions or similar formulations. ${ }^{50}$ It is in this sense that it is possible to speak of a discrete 'global constitutionalist project' in international law. ${ }^{51}$ In this project, the concept of accountability plays an important role. It stands to operationalize a vision of a constitutionalized international legal order. However, as will be shown, as it has developed predominately to alleviate the anxieties of international lawyers, it is a particularly narrow vision.

\section{The contractualism tension: Private (delegated) versus public (constitutional) authority}

A first tension speaks to the relationship between the Security Council and individual member states. The territorially defined, independent sovereign state is traditionally understood as the prototypical actor on the international stage. ${ }^{52}$ According to this orthodox characterization of the international legal order, limitations on a state's freedom of action are only permitted when they are expressly consented to. The converse is also true: states cannot be bound by obligations without their consent. ${ }^{53}$ This orthodoxy suggests that when states are bound to comply with a legal rule, as they are bound to comply with Security Council decisions, the relationship is analogous to a private law contract. The obligation is bilateral and transactional: member states delegate authority to the Security Council and Council decisions gain their binding force from the consent and perceived

50 The trend resonates with D'Aspremont's observation that 'speaking in antinomic terms of the law of international organizations ... constitutes the mainstream style with which this subject is discussed and debated': D'Aspremont (n 48) 140.

${ }^{51}$ For similar uses of the term 'project', see C Schwöbel, 'The Appeal of the Project of Global Constitutionalism to International Lawyers' (2012) 13(1) German Law Review 1; R Collins, 'Constitutionalism as Liberal-Juridical Consciousness: Echoes from International Law's Past' (2009) 22 Leiden Journal of International Law 251. Peters describes global constitutionalism as 'an agenda': A Peters, 'The Merits of Global Constitutionalism' (2009) 16(2) Indiana Journal of Global Legal 397 at 407 . To be clear, though, this is not to suggest that any such uniform 'project' actually exists, and much less that individual scholars would necessarily self-identify as cardcarrying members. The more modest aim is to trace (some of) the normative themes that have prompted the 'turn to constitutionalism' in international law.

52 Indeed, the sources of international law presuppose the interaction of states, and states only, in the formation of international legal rules. See, for example, Statute of the ICJ (1945), art $38(1)$.

${ }^{3}$ This point of departure finds recognition in the Vienna Convention on the Law of Treaties (1969), art 34. 
mutual reciprocity of states. The private law analogy traditionally allowed for the voluntary creation of binding obligations, 'while at the same time preserving the sovereign's independence and authority'. ${ }^{54}$

The 'contractualism tension' emerges when the Council exercises its competence to bind all members in situations where explicit (and often even implicit) consent is lacking. A good example of this predicament is found in the Council's 'law-making' resolutions on terrorist financing. In Resolution 1373, the Council established obligations on states that included the criminalization of certain types of conduct and the freezing of assets of individuals and business entities linked to the funding of terrorism. ${ }^{55}$ To some commentators, the Council's power is executive in nature and is limited to responses to specific 'threats to the peace'. ${ }^{56}$ This is logical, for the imposition of essentially legislative obligations - that is, binding, temporally unlimited and relating to an abstract as opposed to a specific threat - jars with the structural premises of international law, which place the sovereignty of states at its centre. ${ }^{57}$

More than this, though, the nation state's monopoly over the exercise of sovereign power over individuals has always been more than an empirically identifiable reality. To many, it transcended this reality by providing the very roots of, and the context underpinning, the idea of 'public authority', and sovereignty itself, as conceptual phenomena. ${ }^{58}$ In an attempt to transcend the 'contractualism tension', recent developments point to a shift in conceptual understandings of 'public authority'. This novel scheme attempts to redefine authoritative acts of international institutions as instances

${ }^{54}$ F Kratochwil, 'The Limits of Contract' (1994) 5 European Journal of International Law 465 at 465 . This reasoning enjoyed pre-Charter judicial support. In the 1923 Wimbledon case, the Permanent Court of International Justice found that, rather than being incompatible with sovereignty, the ability to voluntarily enter into commitments through international organizations actually represents an attribute of state sovereignty: SS Wimbledon (UK, France, Italy \& Japan $v$ Germany) (Judgment) [1923] PCIJ Rep Series A No 1, at 25. See, similarly, SS Lotus (France $v$ Turkey) (Judgment) [1927] PCIJ Rep Series A No 10, at 18: 'The rules of law binding upon States ... emanate from their own free will as expressed in conventions or by usages generally accepted as expressing principles of law ... Restrictions upon the independence of States cannot therefore be presumed.'

55 UNSC Res 1373 (28 September 2001), para 1(b) and (c).

${ }^{56}$ For example, M Happold, 'Security Council Resolution 1373 and the Constitution of the United Nations' (2003) 16 Leiden Journal of International Law 600.

57 The formalistic response to this 'sovereigntist concern', which holds that ratification of the Charter amounts to implicit consent to be bound by future decisions, is unsatisfactory. Members did not foresee and could not reasonably foresee the various ways in which the Council would (re) interpret its mandate: see Peters (n 35) 784.

${ }^{58}$ Loughlin articulates this position in particularly stark terms, stating that sovereignty is a concept that is 'entirely inseparable from the state': Loughlin (n 17) 73. 
'international public authority'. ${ }^{59}$ Accepting this possibility has a rippling effect on how we might conceive of the nature of international law. From a system based on the principle of jus inter gentes - the law established by states to regulate essentially private relations between states as juridical entities - the 'constitutional' reconfiguration speaks to the principle of $j u s$ publicum. ${ }^{60}$ Its explicit aim is to establish a legal framework for any exercise of public authority, irrespective of its source, and to subject that authority to the requirements of public, or constitutional law. ${ }^{61}$

\section{To what end? Functionalism versus global constitutionalism}

Giving rise to a second tension, the urge to subject the Security Council to public law standards runs contrary to a 'functionalist' impulse that has implicitly undergirded legal discourse on international institutions. ${ }^{62}$ The theory of functionalism relates to the teleological idea that states create international institutions to realize certain commonly held values. ${ }^{63}$ This normative premise traditionally instilled in international lawyers a sentiment that any independence and influence an international institution gained at the expense of its member states contributed to the effective functioning of the institution and the functioning of international law. ${ }^{64}$

Examples of this quasi-romantic inclination towards institutional power are omnipresent in twentieth-century international legal thought. Kennedy, for example, located the move to institutions in turn-of-the-century reformist aspirations that would 'convert passion into reason' ${ }^{65}$ To Claude Jr, this

59 A Von Bogdandy, 'General Principles of International Public Authority: Sketching a Research Field’ (2008) 9(11) German Law Journal 1909.

${ }^{60}$ Ibid 1914.

61 Ibid.

${ }^{62}$ Functionalism's dominance is 'implicit' because international legal scholarship relating to the role of international institutions traditionally has suffered from a dearth of explicit theorizing. Klabbers describes the discipline as 'immature' because it lacks 'a convincing theoretical framework': J Klabbers, Introduction to International Institutional Law $\left(2^{\text {nd }}\right.$ edn, Cambridge University Press, Cambridge, 2009) 3; HG Schermers and NM Blokker, International Institutional Law: Unity within Diversity ( $5^{\text {th }}$ edn, Martinus Nijhoff, The Hague, 2011) 9: 'It is true that theoretical reflection in the field of international organizations has been limited'.

63 See, seminally, D Mitrany, 'The Functional Approach to World Organization' (1948) 24 International Affairs 350. See more recently, J Klabbers, 'The Transformation of International Organizations Law' (2015) 26(1) European Journal of International Law 9; J Klabbers, 'Contending Approaches to International Organizations: Between Functionalism and Constitutionalism', in Research Handbook on the Law of International Organizations, edited by J Klabbers and A Wallendahl (Edward Elgar, Cheltenham, 2011) 1.

${ }^{64} \mathrm{R}$ Collins and ND White (eds), International Organizations and the Idea of Autonomy: Institutional Independence in the International Legal Order (Routledge, London, 2011) 2; Klabbers (n 8) 153; Schermers and Blokker (n 62) 6-7.

${ }^{65}$ D Kennedy, 'The Move to Institutions' (1986) 8 Cardoza Law Review 841 at 859. 
represented 'a secular trend toward the systematic development of an enterprising quest for political means of making the world safe for human habitation' ${ }^{66}$ In its most evocative form, the theory finds its home in the idea that international institutions can provide the 'salvation of mankind'. ${ }^{67}$ While mainstream approaches perhaps use more modest, temperate language, the majority of the discipline's most influential writers have echoed this sentiment:

From Westlake in the 19th century, to Lauterpacht and Kelsen in the mid- $20^{\text {th }}$ century, to Franck and Cassese at the end of the Cold War period ... all, in various ways, placed their hopes in increasingly autonomous international institutions to secure the rule of law in international affairs. ${ }^{68}$

The functionalist mindset held that international institutions were the 'guardians of international law rather than as potential violators'. ${ }^{69}$ It followed, therefore, that the converse must surely have been true: it 'could hardly be seen to engage in activities that would warrant control'. ${ }^{70}$ Even if they did engage in such activities, Mitrany, the archetypal functionalist, denied the 'habitual approach ... that international action must have some overall political authority above it'. ${ }^{71}$

The habitual approach rejected by Mitrany is, in many ways, the very root of the concept of constitutionalism. ${ }^{72}$ To Klabbers, for example, global constitutionalism 'has to do with placing limits on the activities of international organizations, subjecting those organizations to standards of proper behaviour'. ${ }^{73}$ As we have seen, the recent practice of the Security Council shows that any assumption that international institutions comply with the rule of law, let alone secure this value, is increasingly insecure. The appeal of constitutionalist language, therefore, lies in its promise to constrain the excesses of the Council's powers.

${ }^{66}$ IL Claude Jr, Swords into Plowshares: Problems and Progress of International Organisation ( $3^{\text {rd }}$ edn, University of London Press, London, 1965) 405.

${ }^{67} \mathrm{~N}$ Singh, Termination of Membership of International Organisations (Stevens and Sons, London, 1958), cited in Klabbers (n 8) 153.

${ }^{68}$ Collins and White (n 64) 2 (emphasis added).

69 Reinisch (n 8) 131.

70 Klabbers (n 8) 285-86.

71 Mitrany (n 63) 46.

${ }^{72}$ Loughlin describes constitutionalism as simply 'a theory of limited government': M Loughlin, 'What is Constitutionalisation?' in The Twilight of Constitutionalism, edited by $\mathrm{P}$ Dobner and M Loughlin (Oxford University Press, Oxford, 2010) 47 at 55.

73 J Klabbers, 'Constitutionalism Lite' (2004) 1 International Organizations Law Review 31 at 32 . 


\section{The systemic tension: Fragmentation versus global constitutionalism}

If constitutionalism is to do with limits, however, it runs into a final tension. The Security Council is only one of an exponentially increasing body of functionally distinct international institutions. The lack of uniformity or 'fragmentation' between different institutions speaks to a 'systemic' concern, whereby the international legal order is diluted into a set of 'normative islands constituted by partial, autonomous and perhaps even "self-contained" legal sub-systems. ${ }^{74}$ The anxiety is that these sub-systems fail to come together in a unified whole. This is compounded by a 'deformalization' anxiety: in the decentralized, inherently indeterminate international legal space, it is not readily apparent how international institutions can be restrained, regulated and controlled. ${ }^{75}$

The dual anxieties felt by the fragmentation and deformalization tensions speak to different elements of global constitutionalism's allure. ${ }^{76}$ First, the language of constitutionalism alleviates the fragmentation worry by imagining a more integrated, coherent international legal order. ${ }^{77}$ Put in another way, it offers highways between otherwise fragmented, isolated villages. ${ }^{78} \mathrm{In}$ a second move, deformalization is assuaged by instilling a sense of hierarchy, or verticalization, into systematic understandings of international law. ${ }^{79}$ This move is achieved predominantly by elevating particular rules of a supposedly 'constitutional' character over and above so-called 'ordinary' rules. ${ }^{80}$

In this context, the example of $j u s$ cogens norms is particularly illustrative. ${ }^{81}$ According to traditional accounts, the peremptory norms of

${ }^{74}$ M Prost and PK Clark, 'Unity, Diversity and the Fragmentation of International Law: How Much Does the Multiplication of International Organizations Really Matter?' (2006) 5(2) Chinese Journal of International Law 341 at 342.

75 Collins (n 49) 227-31.

${ }^{76}$ For approaches that juxtapose fragmentation with global constitutionalism, see for example J Klabbers, 'Setting the Scene', in J Klabbers, A Peters and G Ulfstein, The Constitutionalization of International Law (OUP 2009) 1; A Peters, 'Fragmentation and Constitutionalization' in The Oxford Handbook of the Theory of International Law, edited by A Orford and F Hoffman (Oxford University Press, Oxford, 2016) 1101.

77 A Paulus, 'The International Legal System as a Constitution' in Ruling the World? Constitutionalism, International Law, and Global Governance, edited by JL Dunoff and JP Trachtman (Cambridge University Press, Cambridge, 2009) 69 at 69: 'in the same vein in which a constitution unifies the domestic polity in one legal superstructure, a developed, institutional reading of international law would unify the international community in a single coherent constitutional structure.'

${ }^{78}$ Klabbers (n 76) 11.

79 Ibid 1: 'Fragmentation, verticalization, and constitutionalization form the holy trinity of international legal debate in the early 21st century.'

${ }^{80}$ See, for example, A Peters, 'Compensatory Constitutionalism: The Function and Potential of Fundamental International Norms and Structures' (2006) 19 Leiden Journal of International Law 579 at 599.

${ }^{81}$ Vienna Convention on the Law of Treaties (1969), art 53. 
international law do not exist to satisfy the preferences of individual states, but for the benefit of the international community as a whole. This speaks to the unifying appeal of global constitutionalism. In turn, jus cogens rules are taken to enjoy a status superior to all other international legal rules, thus representing global constitutionalism's sense of hierarchy. It is telling that the proposition that the Council is bound by jus cogens carries almost unanimous consensus. ${ }^{82}$ The objective, 'constitutional' quality of jus cogens norms surely contributes to this widespread agreement. The interpretation of treaty and customary rules is, comparatively, much more reliant on subsequent (subjective) state attitudes, and there is no such agreement on their status vis-à-vis Security Council decision-making. ${ }^{83}$

\section{Interim conclusion: Accountability and the global constitutionalist project}

The 'turn to accountability' has taken place in the shadows of the broader global constitutionalist project in international law. As a subsidiary discourse within this broader project, accountability stands to operationalize a vision of a constitutionalized order; however, I suggest that this vision is limited. It is limited by the methodological constraints of the project itself, which views 'constitutionalization' not so much as an iterative, organic process, ${ }^{84}$ but in a far more combative sense. This is evidenced by the fact that, more often than not, 'constitutionalism' is invoked in stark juxtaposition to some 'other' theory, be that 'contractualism', 'functionalism', 'fragmentation' or alternative formulations of similar tensions.

In different ways, each of these tensions reflects the incongruity between traditional (state-centric) understandings of international law and the increasingly autonomous nature of international institutional authority. The appeal is in the juxtaposition: constitutionalism provides the tools to

${ }^{82}$ For example, de Wet (n 12) 187-91; Akande (n 31) 332-33; Tzanakopoulos (n 9) 70-72; Henderson (n 13) 499; Hovell (n 12) 99-101. To the extent that courts have broached the matter, the proposition also maintains judicial support - for example, Kadi $v$ Council and Commission (Judgment, Court of First Instance) [2005] Case T-315/01, at paras 192-95; Tadić (n 31) at para 296; Application of the Convention on the Prevention and Punishment of the Crime of Genocide (Bosnia \& Herzegovina $v$ Yugoslavia (Serbia \& Montenegro) (Provisional Measures) (Judge ad hoc Lauterpacht, separate opinion) [1993] ICJ Rep 3, at para 100: 'the duty to comply with obligations that derive from the UN Charter cannot, as a matter of simple hierarchy of norms extend to a conflict between a Security Council resolution and jus cogens'.

${ }^{83}$ Contrast, for example, Tzanakopoulos (n 9) 57-83 with Oosthuizen (n 31) 559-62.

${ }^{84}$ On the notion of an 'organic global constitutionalism', see C Schwöbel, Global Constitutionalism in International Legal Perspective (Martinus Nijhoff, The Hague, 2011) 148-63. 
retrieve 'some form of cognitive control over global political life'. ${ }^{85}$ International lawyers have reached for these tools with both hands. In a move of disciplinary self-sustainment, international law (especially norms of $j u s$ cogens) and international judicial institutions become the bastions of this newly constitutionalized landscape and, by extension, the means through which to realize the accountability ambition.

However, the limitation is also in the juxtaposition. In section II, it was shown that the treatment of Security Council accountability tends to be rather reductive. It revolves disproportionately around the doctrine of international responsibility, leaving several lacunae unresolved. We see now that this reductive treatment is a direct consequence of its implication in the shift to constitutionalist thinking in international law, a shift that is itself reductive in the sense that its raison d'être is to 'resolve the perennial existential insecurity of international lawyers once and for all'. ${ }^{86}$

\section{From existential to internal dynamics: Liberal-legal and political 'styles' of (global) constitutionalism}

It is by no means inevitable that an international legal project of global constitutionalism should display the tensions outlined above. In this section, I argue that these features in fact represent a particular 'liberal-legalist' style of constitutionalism. ${ }^{87}$ This will lay the groundwork for the suggestion in the final section that a (global) 'political constitutionalist' lens might offer important insights on how we should conceive of the accountability of the Security Council. ${ }^{88}$

\section{The 'liberal-legal' style}

In section II, I suggested that the individualization of the consequences of Security Council decisions, coupled with a felt need to constrain the Council's power in the name of protecting individual rights, represents the driving force behind the turn to accountability. These forces resonate strongly with two insights of classical liberalism. The first represents the principle of liberal

${ }^{85}$ D Kennedy, 'The Mystery of Global Governance' in Ruling the World? Constitutionalism, International Law and Global Governance, edited by JL Dunoff and JP Trachman (Cambridge University Press, Cambridge, 2009) 37 at 65.

${ }^{86}$ Klabbers, 'Constitutionalism Lite' (n 73) 48.

${ }^{87}$ On the relationship between liberalism and global constitutionalism generally, see I Ferguson, 'Liberal Theory', in Handbook on Global Constitutionalism, edited by AF Lang and A Wiener (Edward Elgar, Cheltenham, 2017) 106; Collins (n 51).

${ }^{88}$ For examples of the use of this heuristic device in other constitutional contexts, see references cited at $\mathrm{n} 17$. 
individualism-that is, the liberal notion of the propriety of individual rights. It rests on the 'belief that constitutions serve principally to constrain ... power for the benefit of the individual'. ${ }^{89}$ The second represents the liberal inclination that political power arbitrarily exercised is destructive not only of individual liberty but also of the rule of law. Interestingly, by bringing these two aspects together, the global constitutionalist project has been described as a 'paradigmatic of a broader phenomenon of cosmopolitan constitutionalism, based on individual rights guaranteed through a transnational rule of law'. ${ }^{90}$

'Liberal-legalism' is essentially the exercise of mapping the two insights on classical liberalism, individualism and the rule of law with the theory of legalism. It is therefore important to clarify the work 'legalism' is doing in this rubric. The material and ethical dimensions of legalism are best analysed by reference to the work of Judith Shklar. From a material perspective, legalism seeks to elevate judicial processes over and above political processes. To Shklar, the theory implies that 'the court of law and the trial according to law are the social paradigms, the perfection, the very epitome of legalistic morality'. ${ }^{91}$ The idea of 'legalist morality' hints at the ethical dimension of liberal-legalism: it 'holds moral conduct to be a matter of rule-following and moral relationships to consist of duties and rights determined by rules' ${ }^{92}$ From this ethical perspective, the compliance with rules, not the legitimacy of the rules themselves, gives political decisions their value. ${ }^{93}$ Liberal-legalism thus perceives legal rules as a set of rational moral principles. ${ }^{94}$ Legal rationality is portrayed as not merely different from political rationality, but as self-evidently superior to it. ${ }^{95}$ At the international level, this resonates with what Koskenniemi describes as 'a familiar hubris ... the assumption that a right ("lawful", "valid", "optimal", "effective")

${ }^{89}$ MW Dowdle and MA Wilkinson, 'Introduction and Overview', in Constitutionalism Beyond Liberalism, edited by MW Dowdle and MA Wilkinson (Cambridge University Press, Cambridge, 2018) 1 at 1.

90 Wilkinson (n 18) 191.

91 J Shklar, Legalism: Law, Morals, and Political Trials (Harvard University Press, Cambridge, MA, 1986) 2.

${ }_{92}$ Ibid 1.

93 Ibid 104.

94 Loughlin (n 72) 67.

95 In ascribing a 'sanguine, dispassionate quality to law, and specifically to the practice of judicial review', Poole grounds legal constitutionalism in 'a basic opposition of "passions" to "reason": the structuring and tempering, that is, of the dynamic and creative impulses of politics with the inherent reasonableness of settled law': T Poole, 'Judicial Review at the Margins: Law, Power, and Prerogative' (2010) 60(1) University of Toronto Law Journal 81 at 81. 
solution already exists somewhere, and the lawyer's task is just to find it and apply it'. ${ }^{96}$

Drawing these sentiments together, the general theory of liberal-legal constitutionalism represents four themes. First, in its grammar, practices and institutions, law is autonomous to and superior over politics. Second, the exercise of all public authority should be kept in check by law. Third, the most legitimate way of controlling the exercise of public authority is through the judicial articulation and enforcement of broad principles of legality. Finally, the goal of this project is to safeguard a particular vision of individual human rights. ${ }^{97}$

Considering that these themes arise predominantly in the context of domestic constitutionalism, it is telling that global constitutionalism has been described as a scheme that encompasses the following elements:

[T] he exercise of authority in accordance with some version of the rule of law, be it limits internal to the organization (emanating from its own documents) or external to the organization (subjecting it to general international law and human rights standards). And in this scheme, an important role is reserved for judicial review: in the final analysis, judges will be deemed to be the guardians of the rule of law and of the constitution, for they are, many would agree, above politics. Constitutionalism typically aims to tame man's quest for power, and aims to do so by providing legal limits. It stands to reason, then, that individuals trained in the law are deemed most suitable to this task. ${ }^{98}$

Each theme of global constitutionalism maps strikingly to the four themes of liberal-legal constitutionalism outlined above. Where liberal-legal constitutionalism assumes that law is superior to politics, so too global constitutionalism 'tames man's quest for power ... by providing legal limits'. ${ }^{99}$ Where the former claims that all public authority should be kept in check by law, the latter endorses 'the exercise of authority in accordance with some version of the rule of law'. ${ }^{100}$ Liberal-legal constitutionalism implies a preference for judicial over democratic processes, and even when the theory is translated onto the global plane, apparently 'judges will be deemed to be the guardians of the rule of law' ${ }^{101}$ Likewise, global constitutionalism

${ }^{96}$ M Koskenniemi, 'Constitutionalism as Mindset: Reflections on Kantian Themes About International Law and Globalization' (2007) 8 Theoretical Inquiries in Law 9 at 22.

${ }^{97}$ For very similar attempts to categorize the key themes of liberal-legal constitutionalism, see A Tomkins, 'In Defence of the Political Constitution' (2002) 22(1) Oxford Journal of Legal Studies 157 at 158-59; Bellamy (n 17) 3.

98 Klabbers (n 73) 33.

99 Ibid.

100 Ibid.

101 Ibid. 
proposes subjecting (international) public authority to 'human rights standards' ${ }^{102}$ reflecting the individualistic nature of liberal-legalism.

\section{The 'political' style}

The distinctively liberal-legalist origins of the global constitutionalist project go a long way towards explaining the legalized and judicialized nature of the accountability debate. An alternative approach, which evokes a more 'political' style of constitutionalism, owes much to the work of John Griffith. ${ }^{103}$ Its value is found in its antagonism to liberal-legal constitutionalism. To Griffith, the 'concept of law' is not an inherently 'moral concept'. ${ }^{104}$ Instead, the invocation of legal argumentation is itself a 'political act', a statement of a 'power relationship'. ${ }^{105}$ In this general framework, 'law is not and cannot be a substitute for politics'; in fact, 'law is politics carried on by other means'. ${ }^{106}$

Griffith's observations chime with Shklar's critique of legalism, which despite its claim to be exclusively interested in following objective and impartial rules, she suggests is in fact an ideology. Far from representing an apolitical endeavour, it is itself an expression of political preferences. ${ }^{107}$ The logical conclusion of its ideological character, therefore, must be that legalism is just one way among many of conducting political decisionmaking. ${ }^{108}$ To Shklar:

To show that justice has its practical and ideological limits is not to slight it ... The entire aim is rather to account for the difficulties which the morality of justice faces in a morally pluralistic world and to help it recognize its real place in it - not above the political world but in its very midst. ${ }^{109}$

Shklar did not use the language of political constitutionalism-in fact, the lexicon had not, at this stage, crossed the Atlantic. However, the accommodation of different political preferences is a key element of political

102 Ibid.

103 See, for the seminal articulation, J Griffith, 'The Political Constitution' (1979) 42 Modern Law Review 1. Griffith's approach predominantly derived from his experiences of the British constitution, however, importantly for our purposes: 'it is possible to extrapolate ... a more general view about the nature of constitutions and of politics more broadly': M Goldoni and C McCorkindale, 'Three Waves of Political Constitutionalism' (2019) 30(1) King's Law Journal 74 at 76 .

104 Griffith (n 103) 19.

105 Ibid.

106 J Griffith, 'The Common Law and the Political Constitution' (2001) 117 Law Quarterly Review 42 at 59.

107 Shklar (n 92) 4.

108 Ibid 109.

109 Ibid 122-23. 
constitutionalism. The premise that the (international) legal system can rest on impartial rules that guide and circumscribe everyday political disagreement is, of course, unsustainable. States reasonably disagree on the most fundamental questions - whether a situation constitutes a threat to international peace and security, whether enforcement action would be necessary and proportionate to that threat; there simply are no objective answers.

Indeed, the strongest criticism of the myth of homogeneity is that it conceals the inherently contested nature of fundamental issues. Its effect is that 'it postpones, rather than encourages, concrete debates on concrete problems'. ${ }^{110}$ It might even go further than postponing these debates, by shutting them down altogether in favour of the status quo. This produces a form of settlement bias: 'recasting our situation in constitutional terms can give us the feeling things are settled. The struggle is over, and this is how it turned out." ${ }^{111}$ In other words, it tells us that the political struggle is over: the law has literally ruled. On the contrary, rather than striving for objective (legal) answers to the questions that agitate a society of states with competing subjective interests, political constitutionalism offers a structure for reaching collective decisions. ${ }^{112}$

The second theme of liberal-legalism is its innate scepticism towards the exercise of public authority. It champions the limiting power of law. Political constitutionalism, by contrast, proceeds from an innate scepticism towards unrepresentative judicial institutions and aims to show the limited power of law. Instead of taking power away from political institutions and placing it into the hands of the judiciary, political constitutionalism is concerned with understanding the nature of the public authority and the reasons why an institution was originally vested with such authority. The objective is to open the political space to exercise authority in light of this purpose. This approach is, of course, at odds with the methodological tendency to dichotomize global constitutionalist and functionalist perspectives. Instead, it points to a common theoretical heritage between the two. ${ }^{113}$ Just as with the functionalists of international law, to political constitutionalists, 'the

${ }^{110}$ Klabbers (n 73) 50: 'The constitutionalism debate has a great capacity for overshadowing more overtly political debates, with the possible result that an unpopular status quo remains in place'. Tellingly, Peters identifies the possibility of reforming the composition of the Security Council as precisely such a debate that has been 'postponed' by the turn to global constitutionalism: Peters (n 51) 403.

111 Kennedy (n 85) 64.

112 Bellamy (n 97) 5.

113 Indeed, it is commonplace to situate Griffith's 'political constitutionalism' alongside William Robson and Ivor Jennings as descendants of Harold Laski's 'functionalist' school of British constitutional thought. See, for example, M Loughlin, 'The Political Constitution Revisited' 30(1) King's Law Journal 5 at 9-10; Goldoni and McCorkindale (n 103) 75-78. 
very heart of the constitution', its definitive feature, is that it exists to enable government action. ${ }^{114}$

However, political constitutionalism should not be misconstrued as a theory that offers institutions a blank cheque, subject to no limitations. Instead, identifying the original function that an institution is established to fulfil provides the very criterion against which to measure its performance. ${ }^{115}$ This has important implications for a framework of accountability. The criterion for assessment shifts from compliance with the law, to whether the institution has performed its functions effectively in the eyes of the constituency that originally delegated this power.

The reference to the wider constituency speaks to the final line of demarcation between the two 'styles' of global constitutionalism. Liberal-legalism focuses on the relationship between the decision-maker and their affinity to the law. By contrast, political constitutionalism prioritizes the relationship between constituent and constituted power. ${ }^{116}$ Where liberal-legalism suggests that the overriding goal should be to protect individual rights, political constitutionalism adopts a less atomistic perspective, stressing the collective good over individual interests. The 'constituting' aspect of constitutionalism, which speaks to the establishment of institutions for states 'to cooperate and coordinate to pursue projects that they cannot achieve on their own', ${ }^{117}$ is often underplayed in liberal-legal accounts.

Whereas liberal-legalism suggests a rather passive role for 'constituents', who have rights and can expect that these rights will be judicially protected, political constitutionalism offers a more active role. Bellamy argues that 'it is only when the public themselves reason within a democratic process that they can be regarded as equals and their multifarious rights and interests accorded equal concern and respect'. ${ }^{118}$ In international legal theory, it is not uncommon to analogize the role of the state in international law with the role of the individual in the domestic context, in search of the legal order's pouvoir constituant. ${ }^{119} \mathrm{Schmitt}$ brought this analogy to the fore, noting that implicit in the work of Hobbes, Leibniz, Kant and others is the claim that in international law states live as 'moral persons' in a state of nature,

114 Goldoni and McCorkindale (n 103) 75; Griffith (n 103) 15.

115 Klabbers (n 73) 40.

116 Loughlin (n 58) 46 (emphasis added): 'Constitutionalism rests on the principle that constituent power resides in the people, who delegate a limited authority to government to promote the public good. Governors are presented as servants of the people, who are required to account for the powers entrusted to them.'

117 Ibid.

118 Bellamy (n 97) 4-5.

119 J Waldron, 'Are Sovereigns Entitled to the Benefit of the International Rule of Law?' (2011) 22(2) European Journal of International Law 315; R Higgins, 'Conceptual Thinking About the Individual in International Law' (1979) 24 New York Law School Law Review 11. 
confronting one another as sovereign persons with equal legitimacy and equal rights. ${ }^{120}$ The analogy enjoys enduring appeal, as 'states remain the most significant hosts to constitutional discourses, institutions, and structures'. ${ }^{121}$

It is therefore impossible to imagine an accountability framework for the Security Council that does not place the Council's pouvoir constituant, individual member states, at its centre. Member states delegated authority to the Security Council, but this relationship did not cease at this foundational moment; it is ongoing. Under this framework, the Security Council is accountable to member states, and therefore must justify its conduct in light of their demands. It is member states, not (only) international judicial institutions, that enforce the Council's accountability.

Having established that current understandings of Security Council accountability are rooted in the global constitutionalist project, I suggest that this project inherently articulates the contradictions of liberal-legalism. However, if liberal legalism is just one tradition, with a particular understanding of accountability, then we can already see how the lens of political constitutionalism might provide an alternative perspective. The commonality of its various insights is a widening of the institutional actors involved in the accountability process.

\section{The styles of global constitutionalism and the dimensions of Security Council accountability}

In this final section, I return to the three constitutive elements of accountability ('transparency', 'standard-setting' and 'consequences'), noting the various possibilities for the concept of accountability in the Security Council context, depending on the respective 'style' of global constitutionalism adopted.

\section{Transparency}

The first constitutive dimension of accountability is the expectation that an actor will 'give an account' of a decision by explaining and justifying it with reference to reasons. ${ }^{122}$ In theory, the principle of transparency should be

120 See T Poole, 'Sovereign Indignities: International Law as Public Law' (2011) 22(2) European Journal of International Law 351 at 352.

${ }^{121}$ R Prandini, 'The Morphogenesis of Constitutionalism' in The Twilight of Constitutionalism, edited by P Dobner and M Loughlin (Oxford University Press, Oxford, 2010) 309 at 309.

${ }^{122}$ R Mulgan, Holding Power to Account: Accountability in Modern Democracies (Palgrave, New York, 2003) 9: 'Forcing people to explain what they have done is perhaps the essential component of making them accountable.' 
compatible with liberal-legalism. Reason-giving has been characterized as 'one of the essential properties of the concept of the rule of law, if not the essential one'. ${ }^{123}$ The constitutional treaties of international institutions often instil a legal requirement to 'give an account' of decisions. ${ }^{124}$ However, the Security Council is under no such Charter-derived duty to explain or justify affirmative decisions or decisions not to act. Members of the Council may record a statement of explanation before or after a vote; however, they are under no formal obligation to do so and often do not. ${ }^{125}$

Political constitutionalism offers an alternative lens because it goes beyond transparency. It stresses the representative nature of political institutions. From this perspective, the ongoing discourse on reforming the composition of the Security Council in line with shifts in the geopolitical landscape is not separate from, but rather very much a part of, a holistic understanding of accountability. ${ }^{126}$ This shift in perspective also brings the debates on reforming the permanent member veto into an accountability analysis. The emergence of an apparent 'global responsibility not to veto' among the permanent members of the Council in cases of genocide, crimes against humanity and serious violations of international humanitarian law may, in time, potentially yield important (positive) consequences for the effective functioning of the collective security regime. ${ }^{127}$

In sum, while there are widespread calls for the Council to be more transparent in explaining its decisions and permanent members are encouraged to exercise prudence in the use of their veto, these developments have little traction from a liberal-legalist perspective because any reform would be voluntary as opposed to legally mandated. ${ }^{128}$ If these disagreements are to be resolved, it will be in the Council chamber in New York and not in the

123 D Moeckli and RN Fasel, 'A Duty to Give Reasons in the Security Council: Making Voting Transparent' (2017) 14 International Organizations Law Review 13 at 67.

124 See, for example, Consolidated Version of the Treaty on the Functioning of the European Union (2007), art 296. It was held in the Nexans case that Article 296 instils an obligation to 'disclose in a clear and unequivocal fashion the reasoning followed by the institution that adopted that measure in such a way as to enable the persons concerned to ascertain the reasons for it': Nexans SA and Nexans France SAS v Commission (Judgment, Fifth Chamber) [2014] Case C-37/13 P at para 31.

125 Moeckli and Fasel (n 123) 17.

126 See, recently, V Lättilä and A Ylönen, 'United Nations Security Council Reform Revisited: A Proposal' (2019) 30(1) Diplomacy and Statecraft 164.

127 Although, in light of the many unsuccessful attempts to pass resolutions of the General Assembly to concretize this responsibility, even its proponents would admit that this 'responsibility' represents a political commitment rather than a formal legal obligation. See, for example, JBJ Vilmer, 'The Responsibility Not to Veto: A Genealogy' (2018) 24(3) Global Governance 331 at 334 .

128 Amendments to the Charter are subject to the permanent member veto: see, UN Charter (1945), art 108. 
courtroom in The Hague. A political perspective on global constitutionalism will allow us to see these issues as a fundamental part of the accountability discourse.

\section{Standard-setting}

On its own, transparency does not necessarily involve scrutiny. ${ }^{129}$ The notion of standard-setting marks accountability as a particularly reflexive sociological concept. An actor can only be accountable to some 'other', not in the abstract or isolation. ${ }^{130}$ Without this scrutiny, accountability is insufficiently dynamic, because when an 'account' of a decision has been rendered there may still be serious disagreement regarding how it should be assessed. For example, what values should be considered? Whose interests should the accountability forum represent? Indeed, 'accountability cannot be effectively imposed if the criteria against which conduct is to be measured in the process of calling to account are not made clear'. ${ }^{131}$ Standards also have an important role to bear on the scope of the accountability process. They define which aspects of the relevant body's institutional competence the accountability process covers and, implicitly, which it does not.

The two 'styles' of global constitutionalism point to different yardsticks when identifying the relevant standards against which to assess Security Council decisions. As we have seen, the principle of legality is central to liberal-legalism. The importance of a political constitutionalist lens allows for a shifting of the constitutional register, a 'means of contesting or justifying issues in terms of legitimate authority, not merely ... legality or illegality'. ${ }^{132}$

Conventionally, legitimacy is conceptualized as entailing two elements. The first is 'de facto' or 'formal' legitimacy, which is 'akin to the juridical concept of formal validity'. ${ }^{133}$ For the Security Council, this is secured rather straightforwardly. Under Article 24(1) of the Charter, the Council enjoys 'primary responsibility for the maintenance of international peace and

129 M Bovens, 'Analysing and Assessing Accountability: A Conceptual Framework' (2007) 13(4) European Law Journal 447 at 453.

${ }^{130}$ Ibid 450-52; DH Rached, 'The Concept(s) of Accountability: Form in Search of Substance' (2016) 29 Leiden Journal of International Law 317 at 323-26; Mulgan (n 122) 7-14.

131 D Oliver, 'Standards of Conduct in Public Life - What Standards?' (1995) Public Law 497 at 497.

${ }^{132}$ M Kumm, AF Lang Jr, J Tully and A Wiener, 'How Large is the World of Global Constitutionalism?' (2014) 3(1) Global Constitutionalism 1 at 1 . The concept of accountability offers a natural home for these dual discussions about the legality and the legitimacy of Security Council decision-making, as the concept 'has become a cornerstone of current discussion on the prospects of legitimate and effective global governance': Rached (n 130) 317 (emphasis added).

${ }^{133}$ JHH Weiler, The Constitution of Europe (Cambridge University Press, Cambridge, 1999) 80. See further J Raz, The Authority of Law (Oxford University Press, Oxford, 1979) 4-5. 
security'. From a political constitutionalist perspective, it is the second element - the Council's 'de jure' or 'social' legitimacy - that is at stake. Under this rubric, like the concept of accountability itself, legitimate authority can never be exercised in isolation: there 'must be some social group that judges the legitimacy of an actor or action based on the common standards acknowledged by this group'. ${ }^{134}$ It is inextricably dependent upon the social perception and recognition of member states.

The sociological character of legitimacy unveils the segue from the first to the second constitutive dimension of accountability. To scrutinize the Council's conduct, member states must have recourse to a (political) 'right of justification'. ${ }^{135}$ As Wiener shows, this is particularly important for 'less powerful states against the dominance of strong Western states in international institutions'. ${ }^{136}$ This is particularly evident in the case of the Security Council, where permanent members enjoy veto privileges over non-permanent members and decisions are often made in private meetings. Once states are armed with the relevant information relating to why a decision was or was not taken or, in the case of ambiguity, the motivations and intentions of permanent members in choosing a particular wording, their plea to have access to the 'arena of contestation' is answered. ${ }^{137}$

Wiener's second insight is that sociological legitimacy promotes 'regular contestation', as opposed to 'spontaneous contestation'. ${ }^{138}$ If the relevant standards related to legality only, the discourse would be hemmed in by the 'spontaneous', retrospective nature of the doctrine of legal responsibility. ${ }^{139}$ The third insight from Wiener's work on legitimacy is that the meaning of a norm - in this case, accountability - derives not from a norm's fixedness of meaning but from political participation in its definition. This is a crucial insight that carries explanatory force in the context of Security Council decision-making. States might comply with unlawful resolutions, or even refuse compliance with lawful resolutions. De jure legitimacy explains why states engage with Security Council decisions in distinct ways, which should be distinguished from obligation or coercion

134 CA Thomas, 'The Uses and Abuses of Legitimacy in International Law' (2014) 34(4) Oxford Journal of Legal Studies 729 at 748; C Reus-Smit, 'International Crises of Legitimacy' (2007) 44 International Politics 157 at 161: 'The critical thing that differentiates legitimacy is the necessity of social recognition. No action can be coherently described as legitimate if it is not socially recognized as rightful.'

135 A Wiener, A Theory of Contestation (Springer, Dordrecht, 2014) 42.

136 Ibid.

137 Ibid.

138 Ibid 36.

139 See Section II on this particular 'blind-spot' in accountability discourse. 
(international law) and self-interest (international politics). ${ }^{140}$ Indeed, this sentiment has been endorsed strongly by member states:

The effectiveness of the global collective security system, as with any other legal order, depends ultimately not only on the legality of decisions but also on the common perception of their legitimacy - there being made on solid evidentiary grounds, and for the right reasons, morally as well as legally. ${ }^{141}$

The Council relies on member states to implement its decisions. Therefore, as an empirical matter, the Council is primarily driven in its decision-making by the requirement that the wider international community will recognize decisions as legitimate, as opposed to rigorously ensuring that its decisions comply with international law. ${ }^{142}$

\section{The imposition of consequences}

Finally, accountability involves the 'holding to account' phase in which, based on the prior assessment of the actor's conduct, the accountability forum has the power to impose consequences. Some commentators insist that consequences should be formally imposed. ${ }^{143}$ To others, 'the disintegration of public image ... as a result of the negative publicity generated by the process' can be just as effective. ${ }^{144}$ Crucially, whether the consequences are formal or informal will be predicated on the perspective on (global) constitutionalism that is adopted:

A political constitution is one in which those who exercise political power ... are held to constitutional account through political means, and through political institutions ... A legal constitution, on the other hand, is one which imagines that the principal means, and the principal institution, through which the government is held to account is the law and the courtroom. ${ }^{145}$

140 Thomas (n 134) 741.

141 'Report of the High-level Panel on Threats, Challenges and Change' (2 December 2004) UN Doc A/59/565 at para 204.

142 Wiener (n 135) 43: 'the social construction of legitimacy ... is remarkably more important to agents of global governance than legality'.

${ }^{143}$ See, for example, A Schedler, 'Conceptualizing Accountability' in The Self-Restraining State: Power and Accountability in New Democracies, edited by A Schedler, L Diamond and M Plattner (Lynne Rienner, Boulder, CO, 1999) 13, 15-16: 'inconsequential accountability is no accountability at all ... Unless there is some punishment for demonstrated abuses of authority, there is no rule of law and no accountability'.

144 Bovens (n 129) 452.

145 A Tomkins, Public Law (Oxford University Press, Oxford, 2003) 18-19; see similarly G Gee and GCN Webber, 'What is a Political Constitution?' (2010) 30(2) Oxford Journal of Legal Studies 273 at 273. 
Accountability by 'law and in the court-room' is, of course, the central premise of liberal-legalism. However, the primary judicial organ of the United Nations does not explicitly have the competence to review Council decisions. While a lack of express conferral has not provided a barrier to domestic courts interpreting their mandate to include an implied power of judicial review, ${ }^{146}$ there is little evidence to suggest that the International Court of Justice is inclined to assume this role. This is the case for jurisdictional and institutional reasons. From a jurisdictional perspective, states and only states can be parties to contentious proceedings. Decisions will not bind the Council itself even if its members are implicated in a dispute. ${ }^{147}$ From an institutional perspective, the Court traditionally is perceived as functionally horizontal to the Council, as a co-equal organ of the United Nations, as opposed to hierarchically superior. In its Namibia Advisory Opinion, the Court confirmed this relationship, noting that prima facie it is not a constitutional court and 'does not possess powers of judicial review or appeal in respect of the decisions taken by the United Nations organs concerned'. ${ }^{148}$ Such supremacy would be required for the Court to annul Council decisions with binding effect.

In the context of this judicial vacuum, in a recent trend, regional and domestic courts have taken to circumventing their own inability to review the legality of Security Council resolutions by determining that domestic implementing measures are incompatible with the relevant local jurisdictional regime. ${ }^{149}$ The best-known example of this judicial sleight of hand is, of course, the Kadi jurisprudence. In the words of the Court of Justice of the European Union, 'the obligations imposed by an international agreement

${ }^{146}$ It is, in fact, difficult to find any domestic legal regime where judicial review is not expressly prohibited in which judges have not declared that they have this power: Akande (n 31) 326-27.

147 Statute of the ICJ (1945), arts 34(1) and 59.

${ }^{148}$ Legal Consequences for States of the Continued Presence of South Africa in Namibia (South West Africa) Notwithstanding Security Council Resolution 276 (1970) (Advisory Opinion) [1971] ICJ Rep 16, at para 89; Case Concerning the Northern Cameroons (Cameroonv UK) (Preliminary Objections) [1963] ICJ Rep 15, at 33: 'decisions of the political organs of the United Nations could not be reversed by the judgment of the Court'; see further Genocide (Judge ad hoc Lauterpacht, separate opinion) (n 82) at para 99, denying 'any right to the Court to substitute its discretion for that of the Council in determining the existence of a threat to the peace, a breach of the peace or an act of aggression or even the political steps to be taken following such a determination'.

149 See Kadi $v$ Council of the European Union and Commission of the European Communities (Judgment, Grand Chamber) [2008] Joined cases C-402/05 P and C-415/05 P. For examples before other regional and domestic courts, see, Al-Dulimi \& Montana Management $v$ Switzerland (Grand Chamber) [2016] App no 5809/08; Nada v Switzerland (Grand Chamber) [2012] App no 10593/08; HM Treasury $v$ Ahmed and others [2010] UKSC 2 (United Kingdom); Abelrazik $v$ Canada [2009] FC 580 (Canada). 
cannot have the effect of prejudicing the constitutional principles of the EC Treaty'. ${ }^{150}$ To some commentators, this move is reminiscent of a strong dualist construction of the relationship between domestic and international law. ${ }^{151}$ However, for this reasoning to work, domestic and regional courts voluntarily blind themselves to the international legal framework within which they operate. Accordingly, the situation more resembles that of monism, but in reverse. While monism traditionally relates to privileging international law at the expense of domestic law, here domestic law is privileged at the expense of international legal commitments. The decision not to comply with the Council decision is, in terms of international law (and therefore from a liberal-legalist perspective), technically unlawful. ${ }^{152}$

The above critique does not deny the impact of this type of judicial intervention from an accountability perspective. In future resolutions, the Council is not likely to risk a finding of incompatibility, not least because it relies disproportionately on European states for the implementation of its decisions. Crucially, however, this tactic is based on the legitimization of its conduct, as opposed to the legalization of the same. Therefore, it is best understood through a political constitutionalist frame.

Outside the courtroom, political constitutionalism also opens up the potential for member states to exercise an accountability function - for example, by acting through the General Assembly. Indeed, one of the defining features of liberal-legalism is that it centres its gaze on external (judicial) accountability mechanisms rather than internal (political) alternatives. If, as per the wording of Article 24(1), the Security Council acts 'on behalf' of the general membership of the United Nations, it stands to reason that it should be accountable internally to the General Assembly, as the plenary organ where the membership is represented. While the Assembly possesses no formal disciplinary power over the Council, ${ }^{153}$ there may be some potential for the plenary organ to play a role in terms of political accountability. The annual report is a good example of this. In the only reference to the concept of 'accountability' in the Charter, this report should include 'an account of the measures that the Security Council has decided upon or taken to maintain international peace and security'. ${ }^{154}$ As mentioned previously, the annual debate in 2018 may mark an important

${ }^{150}$ Kadi (n 149) at para 285.

151 T Isiksel, 'Fundamental Rights in the EU after Kadi and Al Barakaat' (2010) 16 European Law Journal 551 at 559.

${ }^{152}$ In light of the mandatory nature of Council decisions under Article 25 of the UN Charter, and the supremacy clause found in Article 103.

153 Other than the Assembly's power to 'consider and approve the budget of the Organization', UNCharter (1945), art 17(1).

${ }^{154}$ UN Charter (1945), art 15(1). 
turning point in the willingness of the Assembly to reconceive itself as an accountability forum.

Going further, under the Uniting for Peace resolution, an emergency special session of the General Assembly can be called 'if the Security Council, because of lack of unanimity of the permanent members, fails to exercise its primary responsibility for the maintenance of international peace and security in any case where there appears to be a threat to the peace, breach of the peace, or act of aggression'. ${ }^{155}$ As such, the Assembly could play a conditioning role in relation to Security Council inaction, an aspect of the Council's practice that traditionally has eluded an accountability analysis. Considering the Assembly's constitutional competence, any such determination would lead to a discussion and, at most, a recommendation for collective measures. ${ }^{156}$ Nevertheless, it would be an extremely important statement from the plenary organ of the United Nations from the perspective of political accountability.

The above notwithstanding, we should perhaps be cautious of overplaying the Assembly's role as a formal institutional accountability mechanism, even - or perhaps especially - under a political constitutionalist lens. There are three main reasons. First, through their global alliance systems, the tentacles of the permanent members of the Council penetrate the Assembly deeply, to the point where a blanket condemnation of a Council decision by the Assembly will be rare. ${ }^{157}$ Second, the Assembly's role in the realm of international peace and security is, by definition, subsidiary to the Council's. We have criticized the 'accountability as responsibility' thesis for its reliance on judicial institutions, which breeds an explicitly retrospective form of accountability. To be clear, though, it is not only the nature of the institution - that is, judicial or political - that determines its temporal position in the accountability process; the position of an institution vis-à-vis other institutions is an equally important determining factor. Due to its subsidiary power, once again the Council decision to which the Assembly is responding will have already been made, so the nature of the accountability function will be retrospective.

Finally, and most importantly, the Assembly has no role to play regarding the 1267 sanctions regime, to many the most pressing accountability issue of all. The Sanctions Committee, responsible for all decisions on the listing and delisting of individuals, is made up of representatives of Security Council

155 UNGA Res 377 A (V) (3 November 1950), at para 1.

156 UN Charter (1945), art 10.

157 Although not impossible. For a rare example of the Assembly publicly engaging with the annual report, see UNGA Res 66/253 B (3 August 2012), at 2, 'deploring the failure of the Security Council' to take effective action in Syria. 
member states only. ${ }^{158}$ The Council has thus insulated itself from internal scrutiny through the General Assembly. The only accountability mechanisms available will therefore be external - for example, through the Office of the Ombudsperson, or through individual states or regional organizations refusing compliance. ${ }^{159}$

The final point to consider, therefore, is the status of such non-compliance as an accountability mechanism. It is (theoretically) possible to construct an argument in favour of unilateral non-compliance from a liberal-legalist perspective. Tzanakopoulos, for example, has suggested that unlawful Chapter VII decisions trigger the responsibility of the United Nations. As such, he argues, member states are justified in taking countermeasures to hold the Council to 'account' for this breach, conceptualized as a right of civil disobedience. ${ }^{160}$ Supporting this position, in complying with the Kadi ruling, members of the European Union (indirectly) refused compliance with Security Council Resolution 1267 - itself a form of disobedience.

That said, it is very difficult to move from ad hoc isolated responses to perceived illegality such as the Kadi example to a general legal right to refuse compliance with Security Council resolutions. In any event, even if such a right existed, its designation as a right of 'civil disobedience' would be dubious. It is one thing to argue that civil disobedience is sometimes (politically or morally) justified or even obligatory. This is an intuitive proposition. It is quite another thing to suggest that under certain conditions there is a legal right to civil disobedience. Acts of civil disobedience must necessarily be illegal, otherwise one is faced with the oxymoron of 'legal illegality'. ${ }^{161} \mathrm{In}$ the words of Raz, 'if one has a right to perform it its performance should not be civil disobedience but a lawful political act'. ${ }^{162}$ The positivization of civil disobedience, therefore, is 'neither possible nor advisable since it would divest it of its very essence'. ${ }^{163}$ If civil disobedience is necessarily unlawful, the issue of its justification belongs in the realm of the extra-legal, 'located within a spectrum of (politically motivated) resistance, as a reaction against

158 The ISIL (Da'esh) and Al-Qaida Sanctions Committee, 'Guidelines of the Committee for the Conduct of its Work' (5 September 2018), para 1(b), available at <https://www.un.org/security council/sites/www.un.org.securitycouncil/files/guidelines_of_the_committee_for_the_conduct_ of_its_work_0.pdf>.

$15 \overline{9}$ Of course, these two accountability mechanisms are inexplicitly linked. In UNSC Res 1904 (17December 2009), which established the Office of the Ombudsperson, the Council acknowledged in the preamble that the Office had been established as a direct result of the 'challenges, both legal and otherwise, to the measures implemented by member states'.

160 Tzanakopoulos (n 9) 162-63.

161 Ibid.

162 Raz (n 133) 273.

${ }^{163}$ MJ Falcón y Tella, Civil Disobedience, trans. Peter Muckley (Martinus Nijhoff, The Hague, 2004) 363. 
illegitimate concentration of power'. ${ }^{164}$ The legalist, positivist emphasis of the global constitutionalist project cannot conceptually distinguish between illegality and civil disobedience, so it fails to see how civil disobedience can be an effective tool of (political) accountability.

\section{Conclusion: Oscillating accountability; or, a tale of two (global) constitutionalisms}

This article has provided the first attempt to situate the turn to Security Council accountability within broader theoretical developments in international institutional law. The rise in the functional autonomy of international institutions - of which the practice of the Security Council provides perhaps the best example - has triggered certain existential tensions in the discipline as a whole. The felt need to overcome these tensions drives what might be described as a 'global constitutionalist project' in international law. In the face of such tensions, constitutional analogies provide something of an intellectual comfort blanket. They purport to offer a workable language where conventional private law approaches to international institutional authority are no longer deemed sufficient. Where the teleological rationale that international institutions exist to promote the common good no longer holds, global constitutionalism promises mechanisms of control. It offers the image of a coherent, unified international legal order to transcend systemic anxieties relating to fragmentation and deformalization.

Wherever constitutionalism is invoked, the premise is that the existential tensions somehow cease to be a factor; they give way to the newly constitutionalized international legal landscape. In international legal circles, this narrative tends to be viewed in positive terms: it connotes the idea of 'progress'. ${ }^{165}$ I have attempted to demonstrate the convergences between the progress narrative of the global constitutionalist project and the political theory of liberal-legalism. These convergences are best demonstrated by the fact that, in a veiled move of disciplinary self-sustainment, the apparent rationality and superiority of international law are central to the narrative, and international judicial institutions are elevated to the position of the 'guardians' of this emergent constitutional order.

As a subsidiary discourse within this broader project, 'accountability' has emerged as the conceptual term of art to operationalize this vision of (global) liberal-legal constitutionalism. However, just like its parent concept, the invocation of accountability will invariably carry a normative connotation.

164 Ibid.

165 Collins (n 51) 253. 
Crucially, I have argued that accountability's normative baggage is not separate to, but rather specifically predicated on, the themes of liberallegalism. Juxtaposing global constitutionalism to existential tensions in international law, therefore, can only take the debate so far. It will inevitably lead to a reductive understanding of constitutionalism and, by logical extension, of the value of accountability.

That said, the endeavour to reach a holistic understanding of accountability in the Security Council context does not necessitate throwing the baby out with the bathwater. Instead, the task should be to more explicitly acknowledge the connection between these two sites of discourse: the idea that lurking behind every theory of accountability lies a theory of global constitutionalism. ${ }^{166}$ As such, a distinction that is internal to constitutionalist debates might offer a more appropriate and encompassing frame. I have argued that the meaning, scope and applicability of the concept of accountability turns on the perspective that one takes vis-à-vis two 'styles' of thinking about global constitutionalism. In this tale of two constitutionalisms, the contemporary accountability debate should be viewed in the 'nature of a magnetic field' within which 'liberal-legal' and 'political' styles of constitutionalism 'serve as different poles exerting influence'. ${ }^{167}$

As it stands, the magnetic pull of liberal-legalism is stronger. However, as the Council's legal responsibilities will only be triggered retrospectively, the liberal-legal approach to accountability will inevitably be inchoate. The approach cannot accommodate non-legal aspects of the Council's various accountability deficits, such as ambiguity and inaction. Going further, even when measured against its own terms, the liberal-legal approach is found wanting. The Security Council is under no legal obligation to explain or justify its decision-making processes, the extent to which the UN Charter and general international law provide substantive constraints is clouded in ambiguity and there is no direct mechanism for judicial review. Mainstream approaches thus fail in their original task: in the eyes of international law, the Council does not emerge any more or less 'accountable' in any tangible (positivist) sense.

An alternative approach is necessary to avoid a sense of creeping utopian reformism in which, under the banner of 'accountability', international legal rules and judicial institutions are credited with a 'constitutional' role they were never intended to fulfil. Once the shackles of liberal-legalism are

166 Cf. C Harlow and R Rawlings, Law and Administration (3rd edn, Cambridge University Press, Cambridge, 2009) 1: 'behind every theory of administrative law is a theory of government'; Hovell (n 12) 167.

167 Hovell uses this metaphor to describe the relationship between theory and practice in international law: Hovell (n 12) 163. 
released, a political constitutionalist lens presents new insights into how we might perceive and critique the Security Council, alongside important and distinct ways of understanding and demanding its accountability.

\section{Acknowledgements}

I am grateful to PluriCourts and the editorial team of Global Constitutionalism for organizing the 'New Thinking in Global Constitutionalism' workshop in Berlin in July 2019 and to the participants for their helpful feedback, especially Antje Wiener, Jonathan Havercroft and Andreas Føllesdal. I am also indebted to the anonymous reviewers, as well as numerous colleagues, especially Michelle Farrell, Rob Knox, Mike Gordon, Michael Dougan and Andrew Woodhouse, for insightful and constructive comments at various stages of the article's development. 